\title{
Anticoccidial Activity of Feed Additive Sulfamonomethoxine and Ormethoprim in Chickens
}

\author{
Yutaka NakaI, Keiji OgImoto*, Eiji Ohara**, \\ and Masahiro KATO** \\ Department of Animal Science, Ibaraki University, Ami-machi, \\ Ibaraki-ken 300-03 \\ * Department of Animal Science, Tohoku University, \\ Sendai-shi 980 \\ **Laboratory of Veterinary, Drugs and Chemicals, Research \\ Institute, Daiichi Seiyaku Co., LTD., Tokyo 132
}

(Received October 30, 1987)

\begin{abstract}
Effects of sulfamonomethoxine and ormethoprim $(3 \mathrm{~g}+1 \mathrm{~g} / 100 \mathrm{~g}$ powder: Ektecin Powder) to chicken coccidiosis were investigated. Fourteenday-old chickens were infected experimentally with $10^{4} E$. tenella oocysts. Chickens fed with $1 \%$ Ektecin for 4 days from the next day of infection excreted undetectable number of oocysts, and none of them were killed by coccidiosis. They had almost normal level of serum protein, serum lactate and blood hemoglobin. Their body weight gain, feed intake and feed requirement were better than those of infected infected-non-medicated chickens. Significantly lighter cecal lesions were observed in medicated chickens than in non-medicated ones.
\end{abstract}

Jpn. J. Zootech. Sci., $59(6): 523-526,1988$

Key words : feed additive, anticoccidial, chicken, sulfamonomethoxine, ormethoprim

Activity of sulfonamides against Eimeria species was shown to be enhanced when they were used in combination with some of a group of pyrimidine and triazine compounds ${ }^{1-7)}$. It is known that mixtures of these compounds and sulfonamides interfere with folic acid, dihydrofolic acid and tetrahydrofolic acid metabolism in sequential synthetic pathway of nucleic acid. These mixtures have many benefits of enhanced activity, lower drug concentration, reduced toxicity, quicker clearance of residue and lower possibility of drug resistance.

In the present study, activity of a mixture of sulfamonomethoxine and ormethoprim (Ektecin) against chicken coccidiosis was investigated.

\section{Materials and methods}

1. Medicine

Ektecin (trade name of Daiichi Seiyaku, Tokyo), of which $100 \mathrm{~g}$ powder contained 


\section{Nakai Ogimoto Ohara and Kato}

$3 \mathrm{~g}$ Sulfamonomethoxine and $1 \mathrm{~g}$ Ormethoprim, was used.

2. Experimental infection

White leghorn male chickens were reared with non-medicated feed in wire cages, and chickens were divided into 4 groups (12 chickens each) at the 14th day after the birth. These chickens in groups $\mathrm{C}$ and $\mathrm{D}$ were inoculated orally with $10^{4} \mathrm{E}$. tenella oocysts $\left(\mathrm{K} 2\right.$ strain $^{8)}$ ). Chickens in groups $\mathrm{A}$ and $\mathrm{C}$ were fed with non-medicated feed,

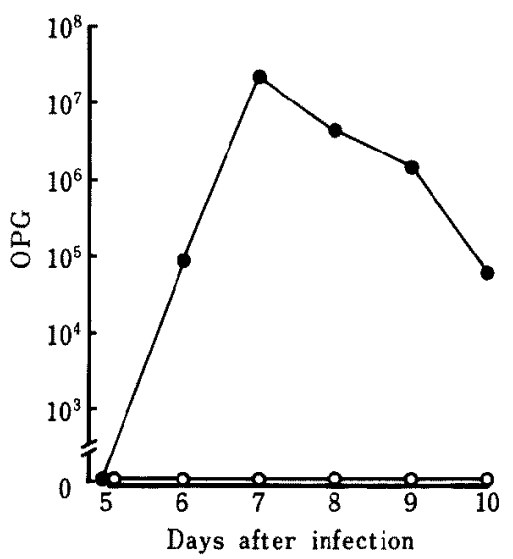

Fig. 1. Oocyst numbers in feces of infected chickens (oocysts per gram of feces: OPG). Chickens inoculated orally with $10^{4}$ E. tenella oocysts were fed with non-medicated feed (-), or with medicated feed (1\% feed additive Ektecin) for 4 days from the next day of infection $(\mathrm{O}-\mathrm{O})$.

Table 1. Effect of Ektecin on chickens infected with $1 \times 10^{4}$ oocysts of E. tenella.

\begin{tabular}{|c|c|c|c|c|c|c|c|c|c|}
\hline Group" & $\begin{array}{l}\text { Mean } \\
\text { body } \\
\text { weight } \\
14 \text { days } \\
\text { old (g) }\end{array}$ & $\begin{array}{l}\text { Body } \\
\text { weight } \\
\text { gain } \\
\text { g/bird) }\end{array}$ & $\begin{array}{l}\text { Feed } \\
\text { intake } \\
(\mathrm{g} / \mathrm{bird})\end{array}$ & $\begin{array}{l}\text { Feed } \\
\text { require- } \\
\text { ment }^{21}\end{array}$ & $\begin{array}{l}\text { Mean } \\
\text { serum } \\
\text { protein } \\
\left(\mathrm{mg} / \mathrm{m} l_{3)}\right.\end{array}$ & $\begin{array}{l}\text { Mean } \\
\text { serum } \\
\text { lactate } \\
(\mathrm{mg} / \mathrm{m} l)\end{array}$ & $\begin{array}{l}\text { Mean } \\
\text { hemo- } \\
\text { globin } \\
\left.\text { (mg } / \mathrm{ml}_{3}\right)\end{array}$ & $\begin{array}{l}\text { Mean } \\
\text { cecal } \\
\text { lesion } \\
\text { score }\end{array}$ & $\begin{array}{l}\text { Morta- } \\
\text { lity } \\
\text { rate } \\
(\%)^{2)}\end{array}$ \\
\hline A & 126.4 & 52.8 & 114.3 & 2.16 & 0.34 & 8.57 & 1.08 & 0 & 0 \\
\hline B & 126.5 & $63.0^{* 41}$ & 112.0 & 1.78 & 0.31 & 6.97 & 1.02 & 0 & 0 \\
\hline $\mathrm{C}$ & 126.3 & $27.1^{* *}$ & 90.4 & 3.34 & $0.22 *$ & 10.43 & $0.62^{* *}$ & $3.5^{51}$ & 33.3 \\
\hline $\mathrm{D}$ & 126.3 & 47.7 & 108.5 & 2.27 & 0.29 & 8.18 & 0.93 & 0.7 & 0 \\
\hline
\end{tabular}

1) Fourteen-day-old white leghorn male chickens (4 groups, 12 each) were inoculated with $10^{4} \mathrm{E}$. tenella oocysts and fed with $1 \%$ feed additive Ektesin for 4 days from the next day of infection (group D). Chickens in group A were non-infected and non-medicated, B were non-infected and medicated, and $\mathrm{C}$ were infected and nonmedicated.

2) Calculations were made from data on the 2nd day to the 6th day after infection.

3) Blood and ceca were investigated on the 6th day after infection.

4) Significant differences from group A were indicated as ${ }^{*} \mathrm{P}<0.05$ and ${ }^{* *} \mathrm{P}<0.01$.

5) There was significant difference between group $C$ and $D(P<0.01)$. 
and chickens in groups B and D were fed with medicated feed $(1 \%$ feed additive Ektecin; final concentration of $300 \mathrm{ppm}$ Sulfamonomethoxine and $100 \mathrm{ppm}$ Ormethoprim) for 4 days from the next day of infection. Numbers of oocysts per gram of feces (OPG) were counted on plankton calculation plates from the 5 th day to the 10 th day after infection. Cecal lesions were scored by JoHnson's methods ${ }^{9)}$ on the 5 th day after infection. Blood components were investigated on the 6 th day.

\section{Results}

Results were summarized in Fig. 1 and Table 1. High numbers of oocysts were detected from feces of infected chickens which were reared without the drug (Fig. 1). Medicated chickens, however, showed undetectable numbers of oocysts. Although 4 of 12 non-medicated chickens were killed by coccidiosis (33.3\%), all of 12 medicated chickens survived (Table 1). The body weight gain of medicated normal chickens (B) was significantly higher than that of non-infected-non-medicated (control) chickens (A). Although the body weight gain of infected chickens which were not medicated (C) was significantly lower than that of control chickens, that of infected chickens treated with Ektecin (D) was similar level of that of the control ones. Feed intake and feed requirement of infected-medicated chickens (D) were better than those of infected-non-medicated chickens $(\mathrm{C})$, and these values of group $\mathrm{D}$ were similar to those of control chickens. In group $\mathrm{C}$, concentration of serum protein and hemoglobin was significantly lower and lactate concentration tended higher than those of control chickens. Concontration of blood components of infected-medicated chickens (D), however, were almost normal levels. Medicated chickens (D) showed significantly lower cecal lesion score than non-medicated chickens (C).

\section{Discussion}

Ektecin prevented oocyst production completely in chickens infected with $10^{4} \mathrm{E}$. tenella oocysts (Fig. 1). Body weight gain, serum protein, serum lactate, hemoglobin and cecal lesions of infected chickens medicated with the drug were not significantly different from those of non-infected control chickens, and their feed intake and feed requirement were similar to those of the control chickens (Table 1). These data indicated that the medication of Ektecin from the 2nd day to the 5th day after infection was effective against experimental chicken coccidiosis by $10^{4} \mathrm{E}$. tenella oocysts. While $50 \%$ effective dose of Sulfamonomethoxine and Ormethoprim against $E$. tenella infection is more than $700 \mathrm{ppm}$ and $200 \mathrm{ppm}$ respectively, the mixture of $300 \mathrm{ppm}$ and $100 \mathrm{ppm}$ respectively was effective in this experiment. This shows that the activity of Sulfamonomethoxine is highly enhanced by the combination with Ormethoprim.

The body weight gain of medicated chickens without infection was significantly higher than that of non-medicated chickens, and their feed requirement was smaller than that of non-medicated ones (Table 1). It is interesting that the drug improved feed efficiency, and resulted in better body weight gain. Therefore, this result may 


\title{
Nakai Ogimoto Ohara and Kato
}

suggest the low toxicity of this drug.

Preliminary experiments were performed in a heavily contaminated farm with coccidia, mainly $E$. tenella and $E$. acervulina. Ten thousand and seventy broiler chickens were treated with $0.04 \%$ feed additive Ektecin twice for 5 days each from the 20 th day after the birth and from the $32 \mathrm{nd}$ day. The numbers of oocysts in feces were reduced transitorily by medication, but the numbers increased to the level of the non-medicated chicken group soon after the medication was stopped. The drug was not fully effective on coccidiosis in that farm under the medication schedule and the dose used. However, this indicates that the remaining period of the drug in the chicken body is very short.

\section{References}

1) Ball, S.J., J. Comp. Path., 74: 487-499. 1964.

2) ClaAkKe, M.L., Vet. Rec., 74: 845-848. 1962.

3) Clarke, M.L., Vet. Rec., 76 : 818-822. 1964.

4) Horton-Smith, C., P.L. Long and H.O. Collier, Brit. J. Pharmacol., 15 : 298-303. 1960.

5) Joyner, L.P. and S.B. Kendall, Nature, 176:975. 1955.

6) JoYNer, L.P. and S.B. Kendall, Brit. J. Phermacol., 11 : 454-457. 1956.

7) Lux, R.E., Antibiotics and Chemotherapy, 4: 971-977. 1954.

8) NakaI, Y. and K. OGrmoto, Jpn. J. Vet. Sci., 44: 951-956. 1982.

9) Johnson, J. and ReID, W.M., Exp. Parasitol. 28 : 30-36. 1970.

\section{飼料に添加したスルファモノメトキシン・オルメトプリム合剤の 鶏コクシジゥム症に対する影響}

\author{
中井 裕・扇元敬司 ${ }^{*}$ ・大原英治 ${ }^{* *}$ - 加藤正博** \\ 茨城大学農学部, 茨城県稲敷郡阿見町 300-03 \\ *東北大学農学部, 仙台市 980 \\ ** 第一製薬中央研究所, 東京都江戸川区 132
}

スルファモノメトキシン・オルメトプリム合郕である エクテシン散の抗コクシジウム作用を14日令の鶏七ナ にE. tenellaを人工感染させて調べた。オーシスト接 種後 4 日間にわたる薬剤添加飼料の給与によって, 致死 率の低下と著明なオーシスト排泄の排制が見られた。 ま
た盲腸病変は著しく軽度で，血液中の乳酸，血清蛋白 は正常ヒナのレベルを示し, 飼料摂取量, 増体量, 飼料 要求率の改善屯認められた。

日畜会報， $59(6): 523-526,1988$ 